\title{
THE MASK(S) AND TRANSFORMERS OF HISTORICAL RE-ENACTMENT MATERIAL CULTURE AND CONTEMPORARY VIKINGS
}

\author{
Dawid Kobiałka
}

\begin{abstract}
The paper discusses the role of material culture for historical re-enactors of the Viking Age. Three issues are analysed: (a) the clothing and accessories worn by a typical contemporary warrior, craftsman and woman of the Viking times and the range of goods available for purchase at historical re-enactment markets, (b) the active and transformative aspect of material culture for present-day Vikings, (c) the paradox of how mirroring the material past by historical re-enactors is actually a deeply ahistorical category. The main conclusion of this study is that historical re-enactment of the Viking Age is essentially about material culture. The paper is based on observations made during the Viking Week that took place at the Museum of Foteviken (Sweden) on 24-30 June 2013.
\end{abstract}

Keywords: material culture, historical re-enactment, archaeological open-air museums, popular culture

\section{INTRODUCTION}

It may be said that, paradoxically, the greater contemporary man's fascination with the present and the future, the deeper his interest in the past (e.g. Lowenthal 1985:chapter I, 1996). This process has many aspects. The increasing economic value of cultural tourism is just one ex- 
ample. The mysterious Egyptian pyramids, Greek ruins, etc. are visited by millions of people every year (Melotti 2oII). Another example, the subject of this paper, is the historical re-enactment milieu that practises its way of life during historical re-enactment events, often at archaeological open-air museums (Goodacre \& Baldwin 2002).

The popularity of both archaeological open-air museums and historical re-enactment is a quite recent phenomenon (Rentzhog 2007). Despite the fact that the first open-air museums were already being built in the late I9th century (Magelssen 2007; Paardekooper 20I2:chapter 2), it is only really during the last 30 years that they have become popular and can be found in most parts of Europe. According to Paardekooper (20I2:23), it is safe to say that nowadays there are almost 300 archaeological open-air museums in Europe alone, and this number is likely to increase in the near future (e.g. Petersson 2003). There are a number of definitions of the archaeological open-air museum. The one applied in this study states that an archaeological open-air museum is:

a non-profit permanent institution with outdoor true to scale architectural reconstructions primarily based on archaeological sources. It holds collections of intangible heritage resources and provides an interpretation of how people lived and acted in the past; this is accomplished according to sound scientific methods for the purposes of education, study and enjoyment of its visitors (Paardekooper 20I 2:289).

Similarly, the last 30 years have witnessed the development of historical re-enactment into a widespread social and cultural phenomenon (e.g. Agnew 2004, 2007). Historical re-enactment can be understood, in its broadest sense, as: any attempt to recreate a historical event of a specific historical period (Petersson 2010:5). I observed and actively participated in historical re-enactment events in Poland (e.g. Wolin, Biskupin, Kalisz Zawodzie, Gniezno) and Sweden (e.g. Birka, Öland, Trelleborg, Höllviken) in 2OI2-20I3. Instead of discussing all of these places and the events that were held there, I have decided to focus on one case study: the Viking Week at the Museum of Foteviken. As this is quite a popular event among present-day Vikings from many countries it was assumed that the market would serve as a good example from which to approach the complexity of historical re-enactment of the Viking Age.

The Museum of Foteviken (Fotevikens Museum) in Höllviken is an archaeological open-air museum that is located in the south-western part of modern-day Sweden (figure I) (Rosborn 2004, 2005). The museum was founded in 1995 and it is a reconstruction of a Viking town with many different facilities. By 2008 , the museum consisted of 23 dif- 


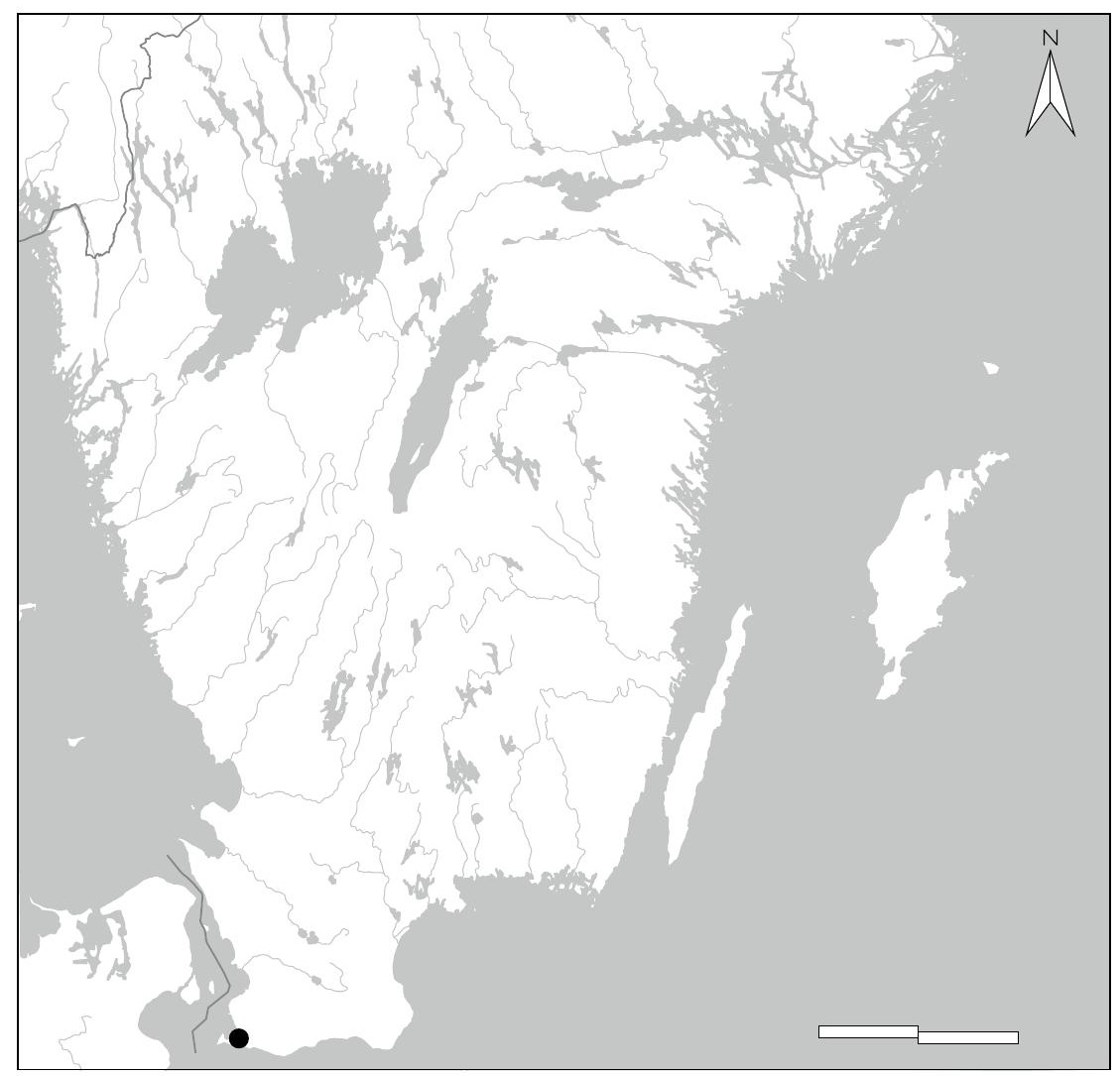

Figure I. Map of the southern part of Sweden with the location of the Foteviken Museum in Höllviken.

ferent reconstructions of buildings from the late Viking Age and Early Middle Ages (Fotevikens Museum 20I3a; Paardekooper 20I 2:I89-20I).

Since 1995 the museum has organized numerous historical re-enactment events including the Viking Market where, for a few days of the year, historical re-enactors can live as if they were Vikings. They wear clothes that are supposed to mirror Viking times, produce material culture as was used during the period and so on. In short, the historical re-enactors of the Viking Age try to bring the lost and dead past to life. These people are very present but at the same time they dream of living in the past. This - let me call it - contradiction is embodied in the term that is used in this paper to refer to them: contemporary Vikings. The Museum of Foteviken invites such people to participate in the diverse events it organizes. A total of 620 historical re-enactors of the Viking Age from I5 countries took part in the gathering I attended on 28-29 June 20I3. The fact that I0,000 tourists visited the museum during the 
Viking Week is also worth mentioning (Kobiałka 20I3). The event itself was very similar to other Viking historical re-enactment festivals that I had taken part in before, there were reconstructions of Viking buildings and many white linen tents. These tents had a dual purpose for they were a place to sleep at night and could be converted into a market stall by day.

Entering an archaeological open-air museum is like travelling in time into the distant past. Such time travel is - as Holtorf (2010:33) points out - "an experience and social practice in the present that evokes a past (or future) reality". The staff of the Museum of Foteviken must be well aware of this new social way of experiencing the past. As one of the information boards in the museum declared: Start your time travel here! (Starta din tidsvandring här!). This explains why contemporary items such as beer cans, mobile phones and so on were rarely visible within the Viking Reserve. Nothing could disturb contemporary man's journey in time.

I observed and conversed with present-day Vikings from countries such as Sweden, Poland, Denmark, and the UK during the market. Most of the contemporary Vikings were craftsmen, people who came both to sell their products and simply to enjoy the time travel experience. Some of the re-enactors were warriors who had the opportunity to show off their skills during the battle re-enactments prepared by the organisers. Another group of Vikings was made up of those who had come to the $\mathrm{Mu}-$ seum of Foteviken to practise their hobby, or as many openly admitted, their way of life. The organizers prepared events for tourists such as fish throwing or archery competitions. During these events the present-day Vikings tried to engage the tourists in time travel (see also Svendsen 20I0).

\section{MATERIAL CULTURE AND CONTEMPORARY VIKINGS}

During the market it was easy to distinguish a historical re-enactor of the Viking Age from a tourist. In short, the historical re-enactors were created and defined as historical re-enactors by their peculiar material culture: clothing, weaponry, jewellery, drinking vessels etc. (Kim Siddorn 2000). During the first day of the research, one of the re-enactors even explained to me that "it is impossible [for him] to be a true historical re-enactor without all this 'stuff'" (Mietek 20I3; author's translation). By "stuff", he meant the material things which he was wearing. Therefore it was not knowledge that was relevant in re-enactment, but things, objects that looked as if they were from the Viking Age. Very similar logic was easily discernible during discussions with other historical re-enactors as well. 
The worst thing that a historical re-enactor of the Viking Age can be accused of concerns material culture. It is still acceptable not to know some obscure details of Norse mythology. However, it is a serious problem when someone, and I quote a fragment of a conversation with a contemporary Viking woman from Poland - "confuses things from different historical times" (Ania 2013; author's translation). This means that the historical re-enactor is in real trouble. So it is insufficient simply to have historical-looking things. According to historical re-enactors, the objects they have must mirror the past material culture as much as possible.

Although objects that appear to be replicas of archaeological finds from the Viking Age (which is usually not true) are an essential aspect of this kind of historical re-enactment, the issue of material culture among historical re-enactors is still poorly understood. If archaeology is the discipline of things (Olsen et al. 20I2), then an archaeological interpretation of historical re-enactment should hinge upon things produced, used and sold by the re-enactors themselves. So far, though, this has not been a dominant perspective.

The analysis of historical re-enactment usually concerns more general trends; how it reveals something about the contemporary world and society. Such a perspective is predominant e.g. in a book Historical Re-Enactment: From Realism to the Affective Turn edited by McCalman and Pickering (20IO), which discussed problems such as how re-enactment is an example of the affective turn, the role of realism in re-enactment, or Collingwood's comprehension of re-enactment, among other things. Similarly, Halewood and Hannam (200I), in their analysis of what they call Viking heritage tourism, bring the discussion down to the authenticity and commodification of the past. The things used by present-day Vikings are somehow of lesser importance. This would be also a weak point in Holtorf's (e.g. 20Io) account of the time travel phenomenon. It is still material culture which is the medium of any time travel into the past, at least for the historical re-enactors themselves (see also Holtorf 20I3). Historical re-enactment can also be seen through the lens of $\mathrm{Ba}-$ udrillard (1994) as simulacra (Pawleta 20II:I7): as copies that do not refer to any original objects.

During the Viking Market it was possible to come across craftsmen, the majority of whom were male, such as smiths, gold and silversmiths, potters, cobblers or bone carvers, among others, producing different objects. The warriors were also predominantly male. Viking women usually sold clothing or jewellery. The historical re-enactors attempted to mirror different social classes during the event; that is why a craftsman used different objects from, say, a warrior. Of course, the clothing worn 


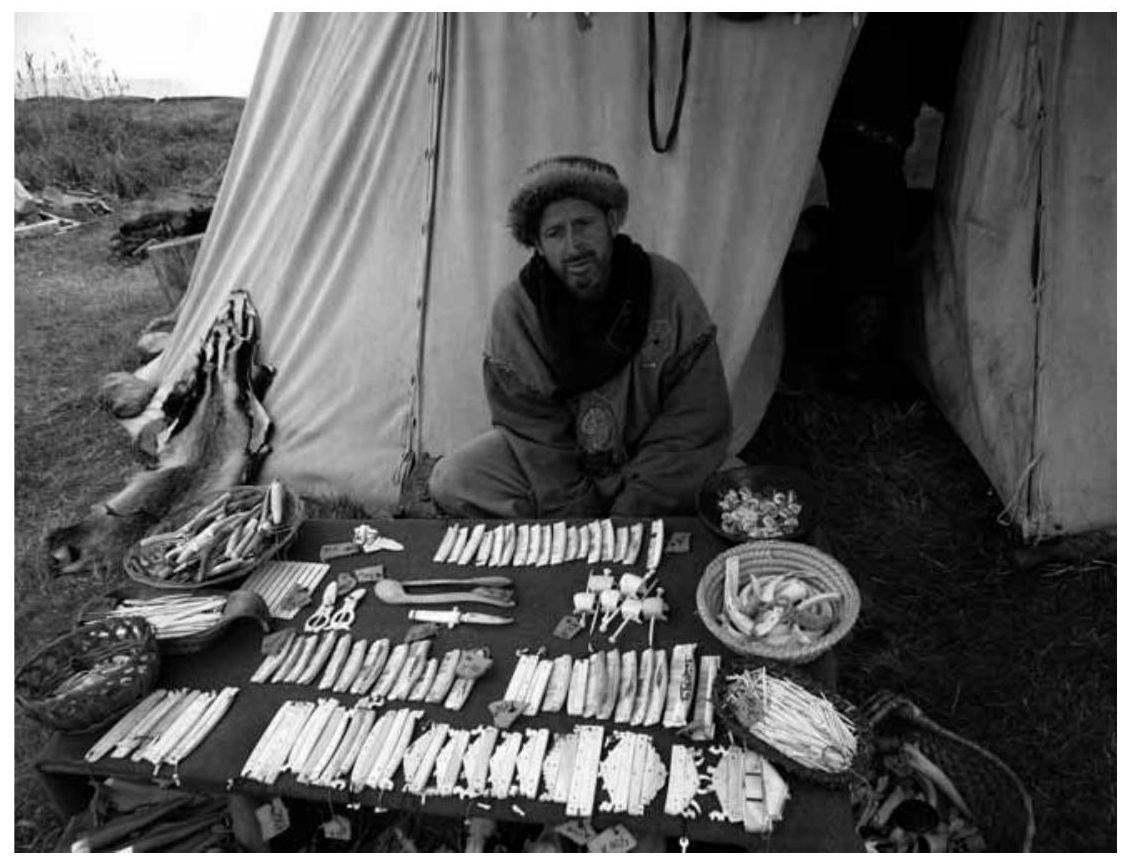

Figure 2. A craftsman during the Viking Market. Photo: Dawid Kobiałka.

by the present-day Viking women during the market was very different from that of the men (compare figure 4 below).

A craftsman can be considered a typical contemporary Viking (figure 2). He wore a woollen hat together with a linen hood as well as a long robe and trousers. His shoes were made of leather, as was his belt and the small purse in which he carried contemporary Swedish kronor. Craftsmen did not usually wear expensive silver or glass jewellery.

Contemporary Viking warriors looked quite different from the craftsmen during the event. Figure 3 presents the material culture used by one such warrior: a helmet in the fashion of an archaeological artefact as well as a sword and a wooden shield. Warriors had to wear leather lamellar armour during battles. Their clothes were linen, with leather shoes and a belt, and they also had a small knife and expensive necklaces and bangles made of silver.

Present-day Viking women, on the other hand, invariably wore long dresses (figure 4) and could often be seen with a leather belt, small belt pouch and a knife. Likewise, their shoes were made of leather too. Many women also wore a lot of jewellery. As I discovered from some historical re-enactors from Poland this has, rather ironically, been dubbed the Christmas tree syndrome. This describes present-day Viking women wearing all the jewellery they own at once during historical re-enactment 


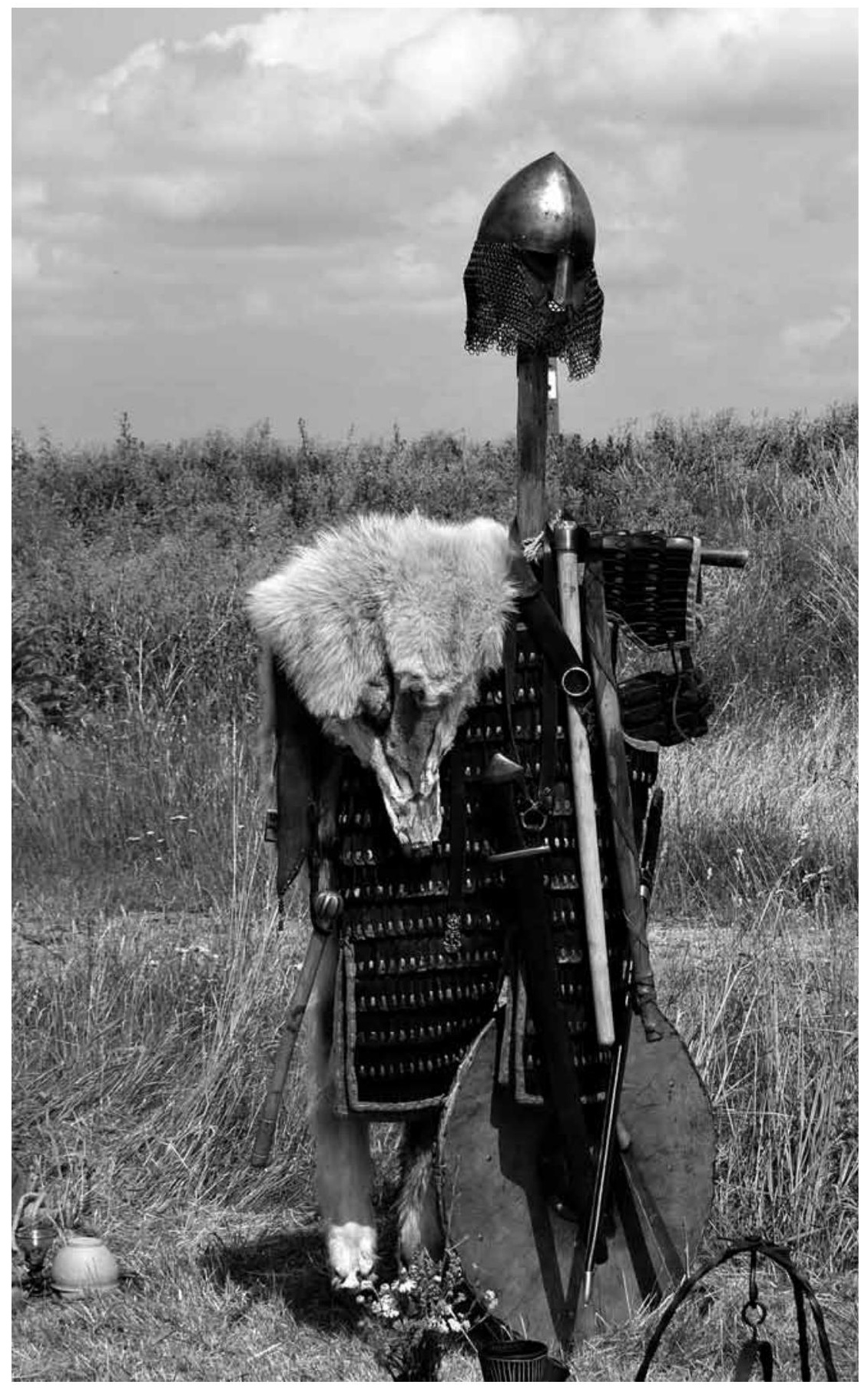

Figure 3. Equipment of a Viking warrior during the Viking Market. Photo: Dawid Kobiałka. 


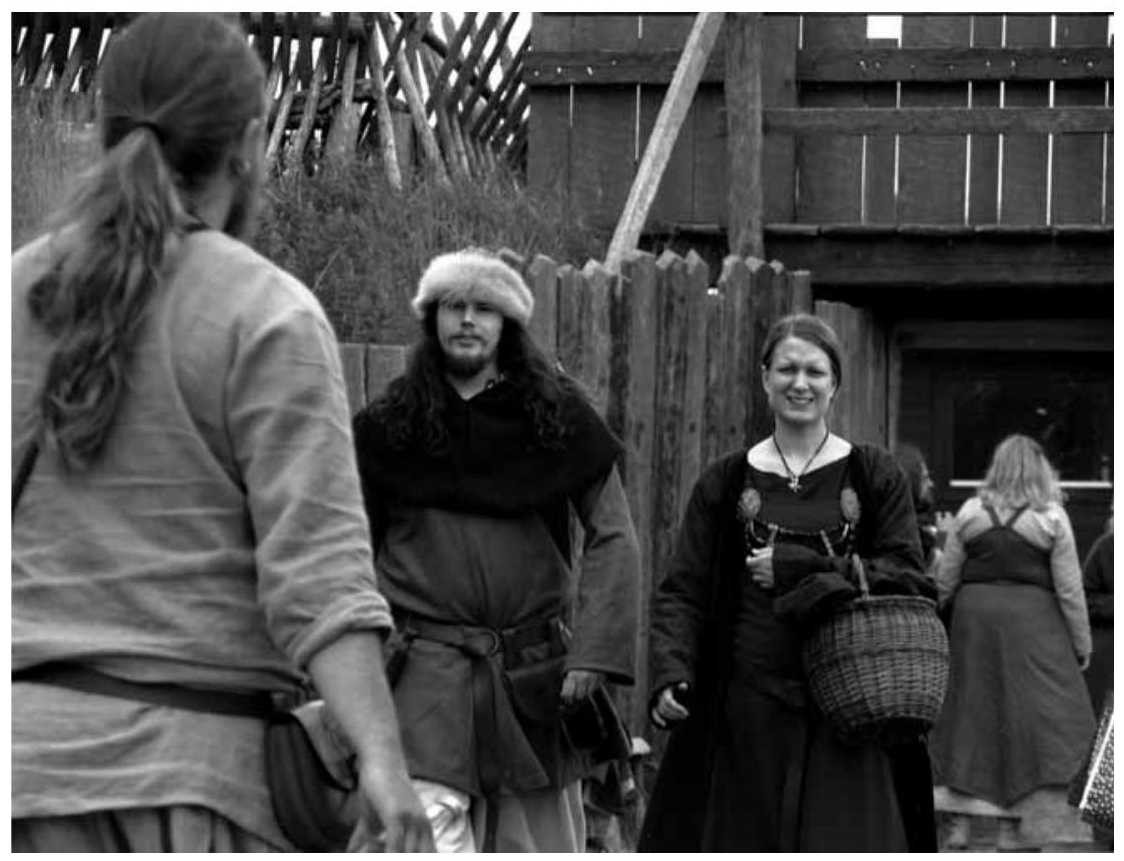

Figure 4. A Viking woman during the Viking Market. Photo: Dawid Kobiałka.

Figure 5. Material culture produced by a Swedish historical re-enactor. Photo: Dawid Kobiałka. 


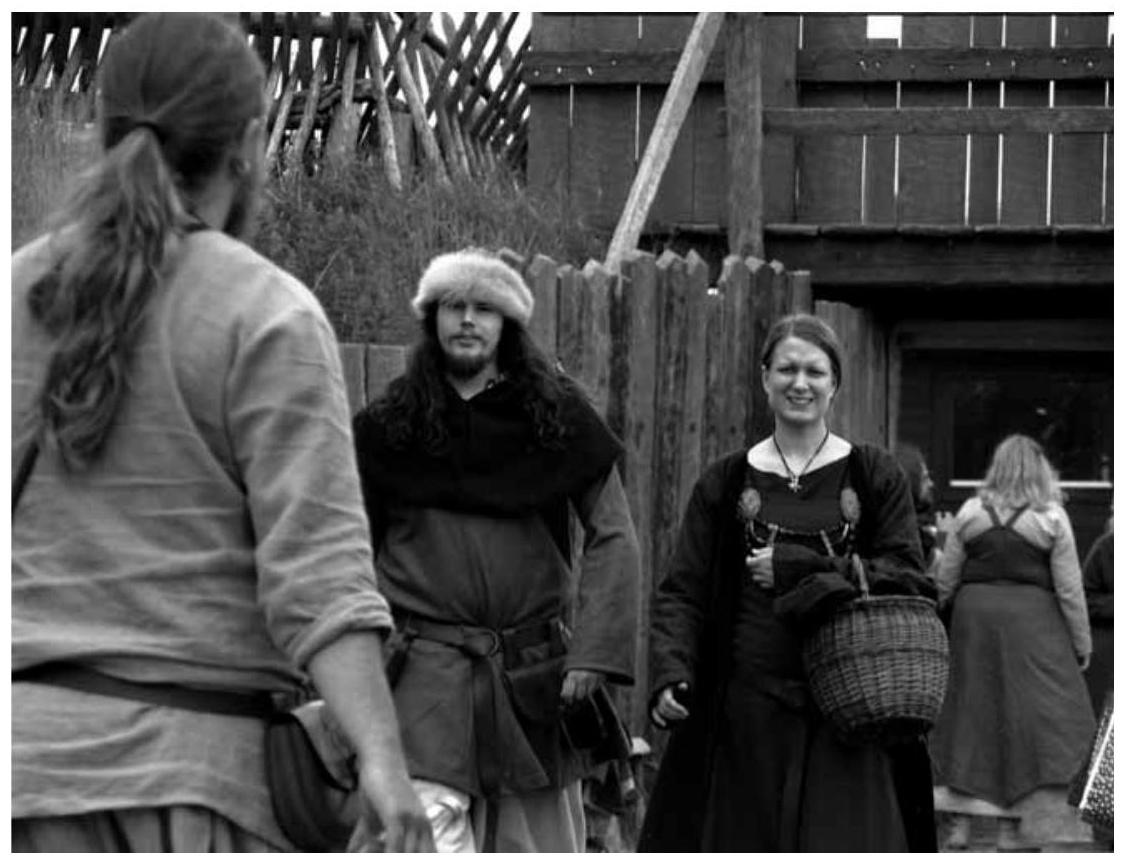

Figure 4. A Viking woman during the Viking Market. Photo: Dawid Kobiałka.

Figure 5. Material culture produced by a Swedish historical re-enactor. Photo: Dawid Kobiałka. 


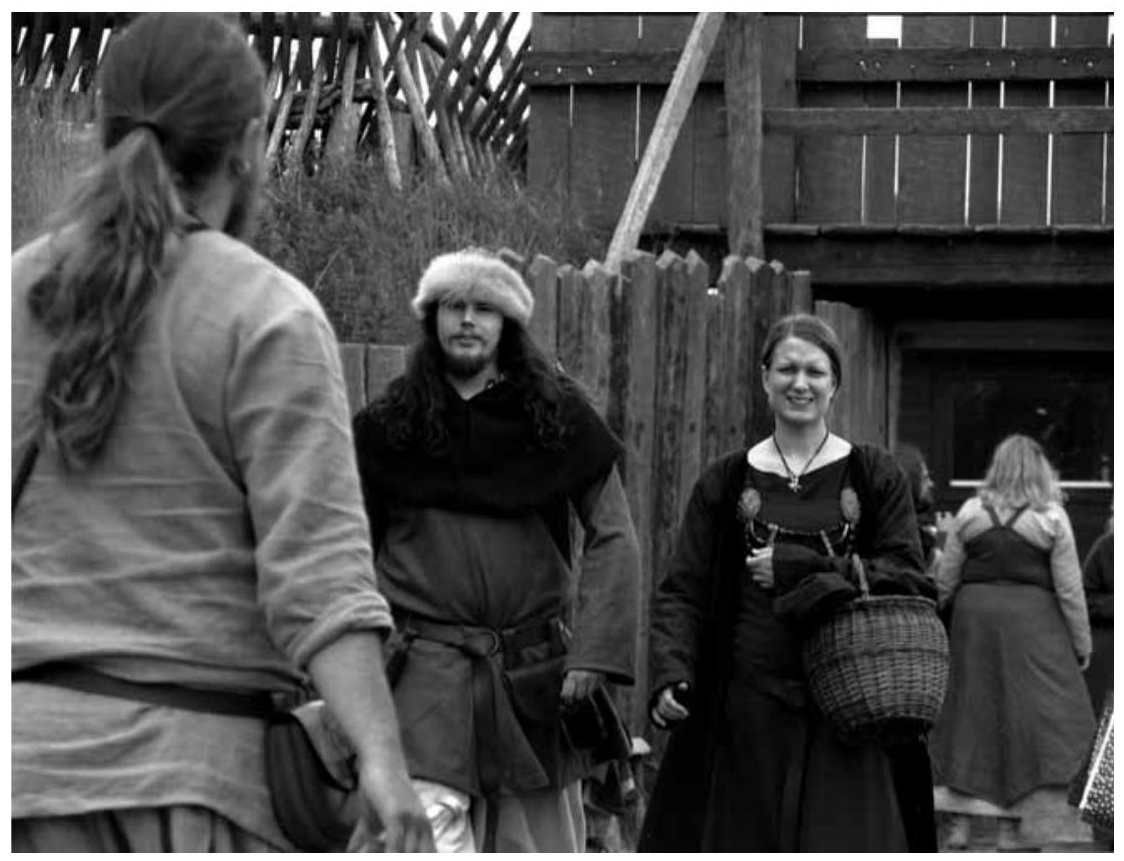

Figure 4. A Viking woman during the Viking Market. Photo: Dawid Kobiałka.

Figure 5. Material culture produced by a Swedish historical re-enactor. Photo: Dawid Kobiałka. 


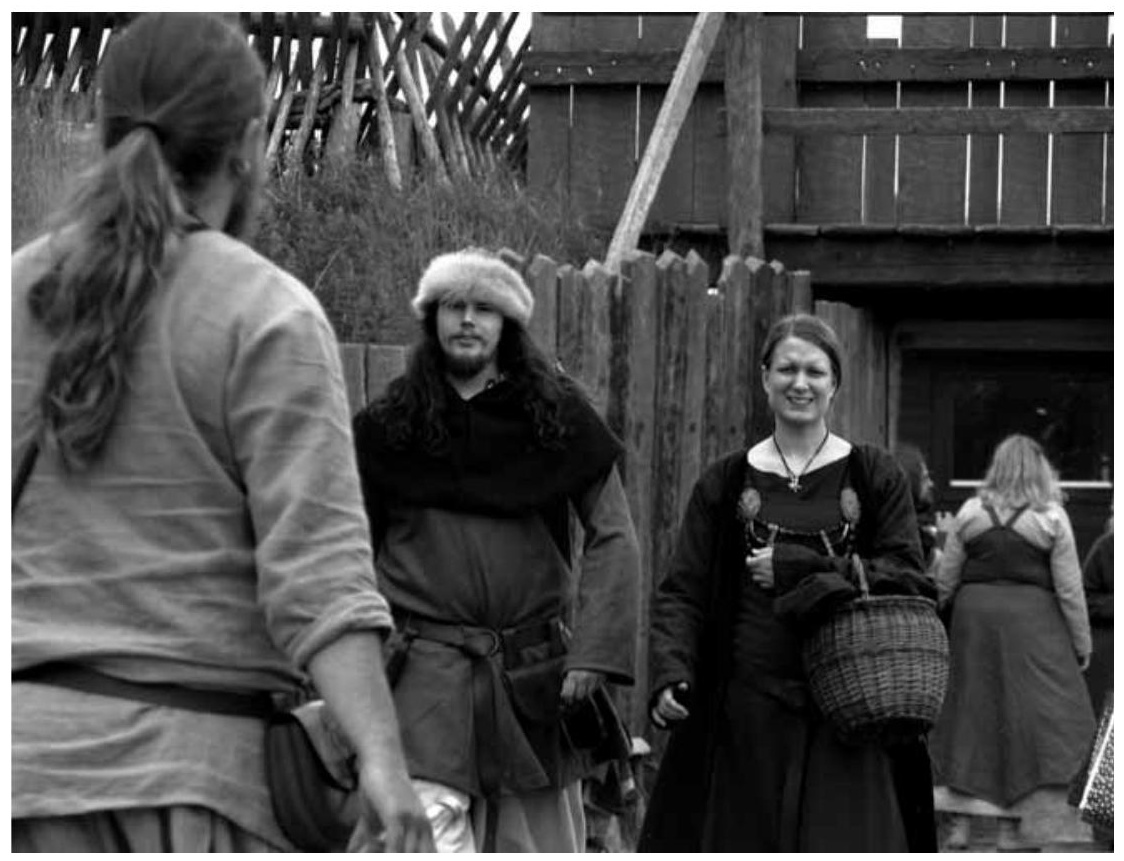

Figure 4. A Viking woman during the Viking Market. Photo: Dawid Kobiałka.

Figure 5. Material culture produced by a Swedish historical re-enactor. Photo: Dawid Kobiałka. 


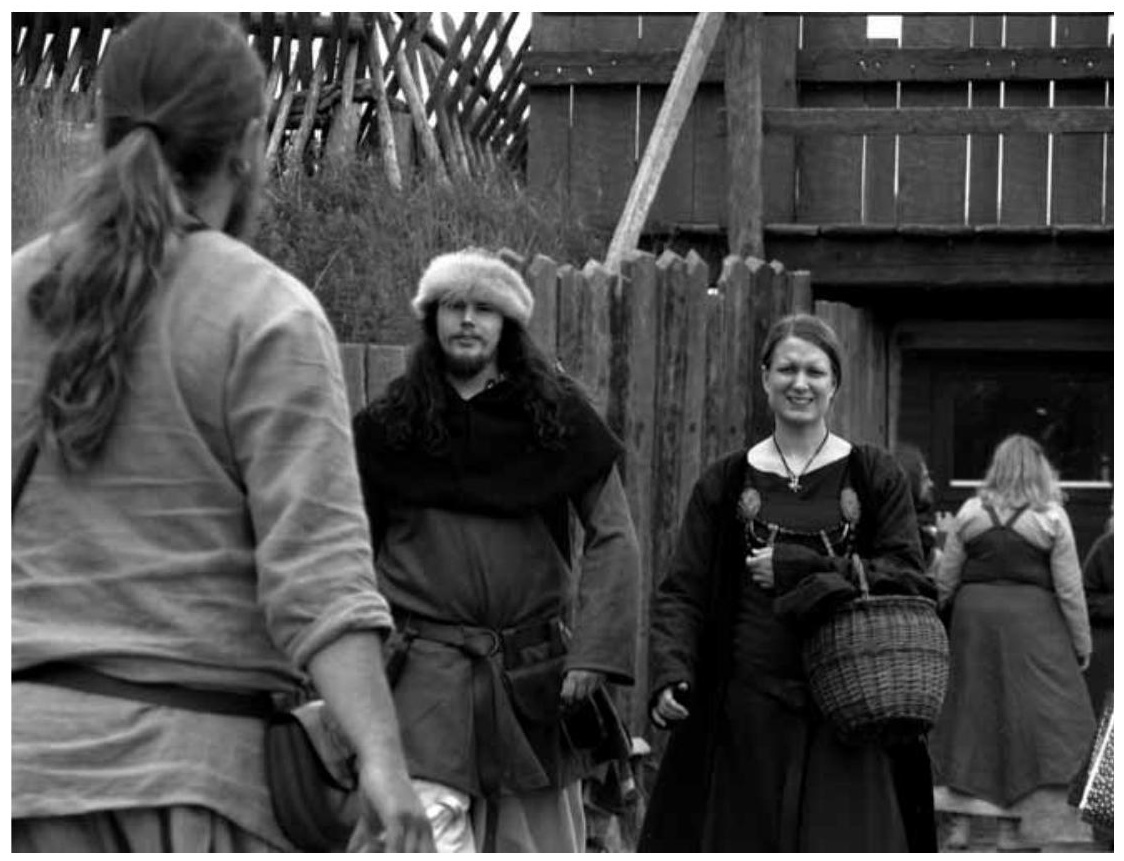

Figure 4. A Viking woman during the Viking Market. Photo: Dawid Kobiałka.

Figure 5. Material culture produced by a Swedish historical re-enactor. Photo: Dawid Kobiałka. 


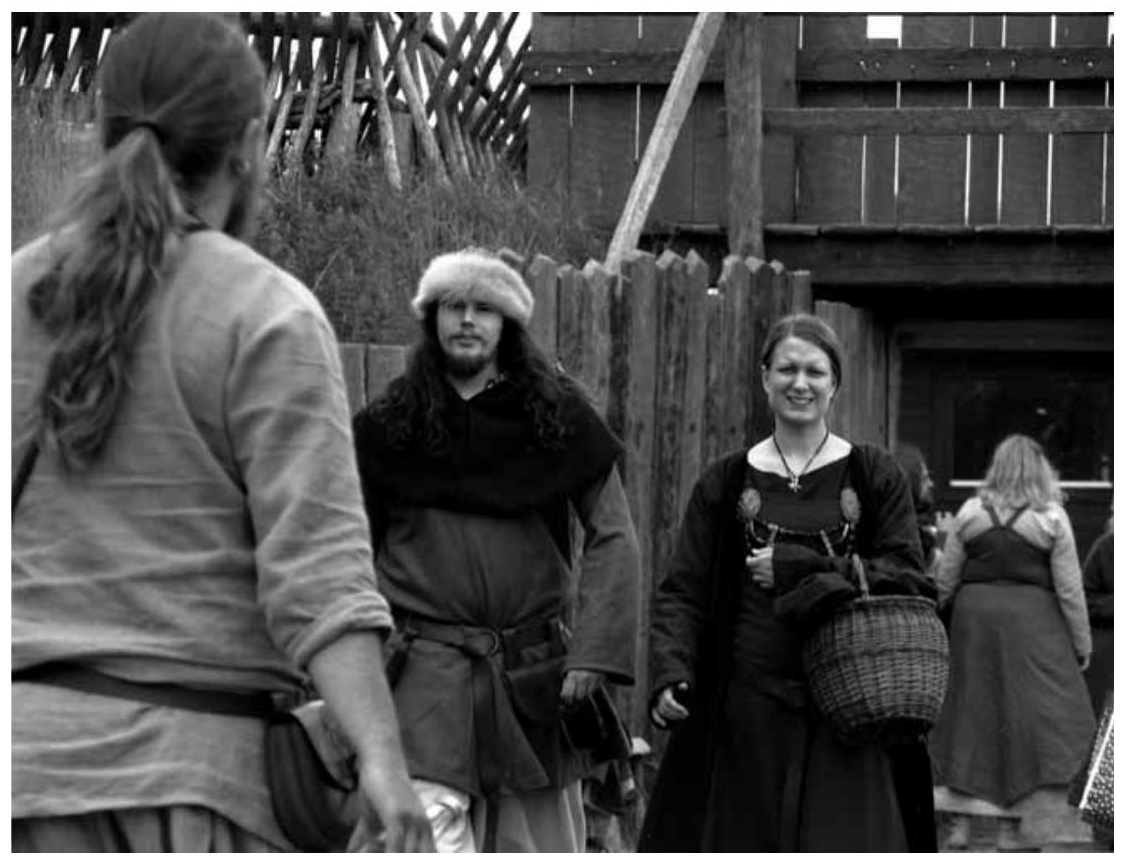

Figure 4. A Viking woman during the Viking Market. Photo: Dawid Kobiałka.

Figure 5. Material culture produced by a Swedish historical re-enactor. Photo: Dawid Kobiałka. 


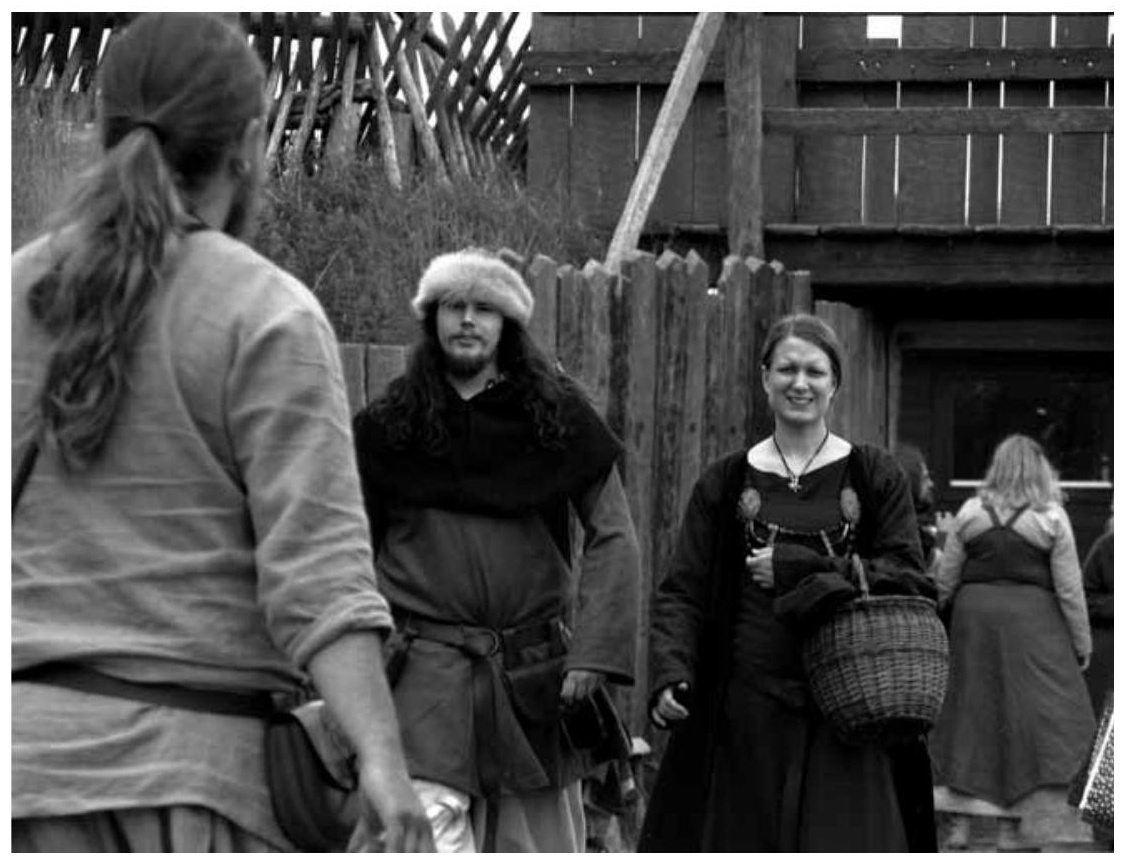

Figure 4. A Viking woman during the Viking Market. Photo: Dawid Kobiałka.

Figure 5. Material culture produced by a Swedish historical re-enactor. Photo: Dawid Kobiałka. 


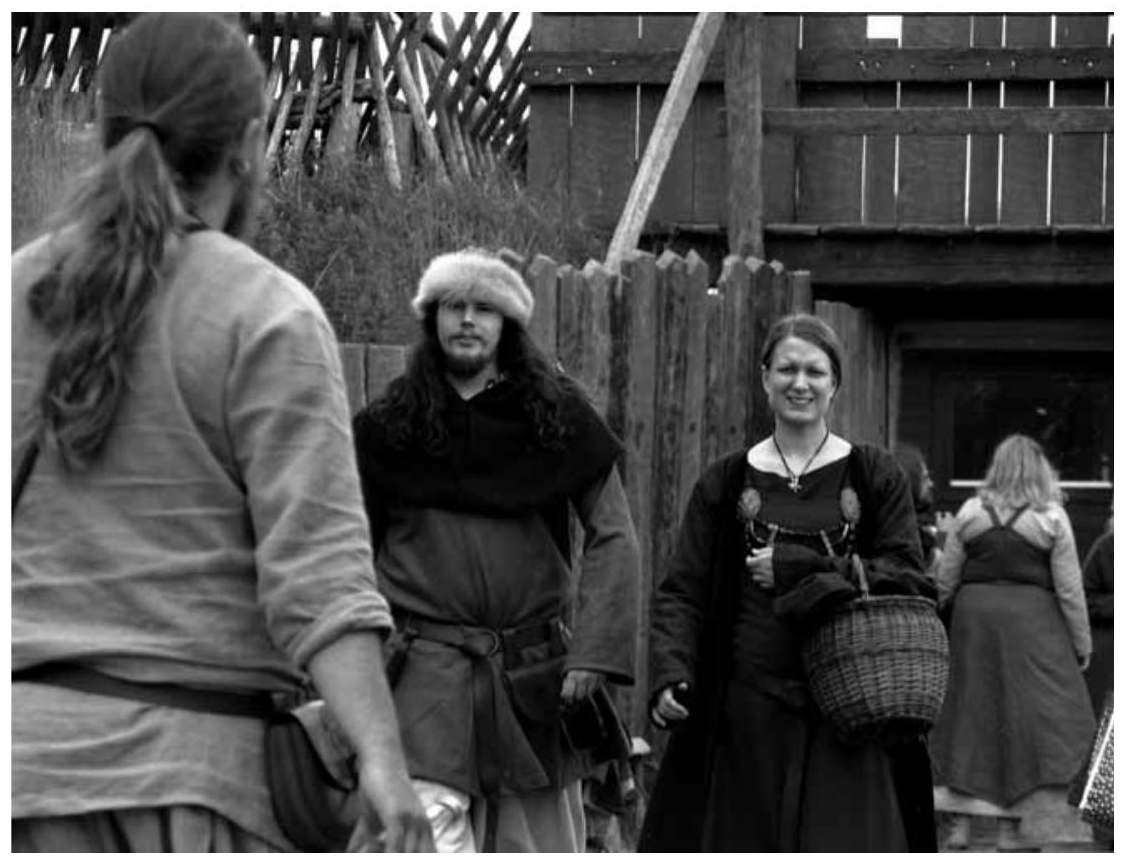

Figure 4. A Viking woman during the Viking Market. Photo: Dawid Kobiałka.

Figure 5. Material culture produced by a Swedish historical re-enactor. Photo: Dawid Kobiałka. 


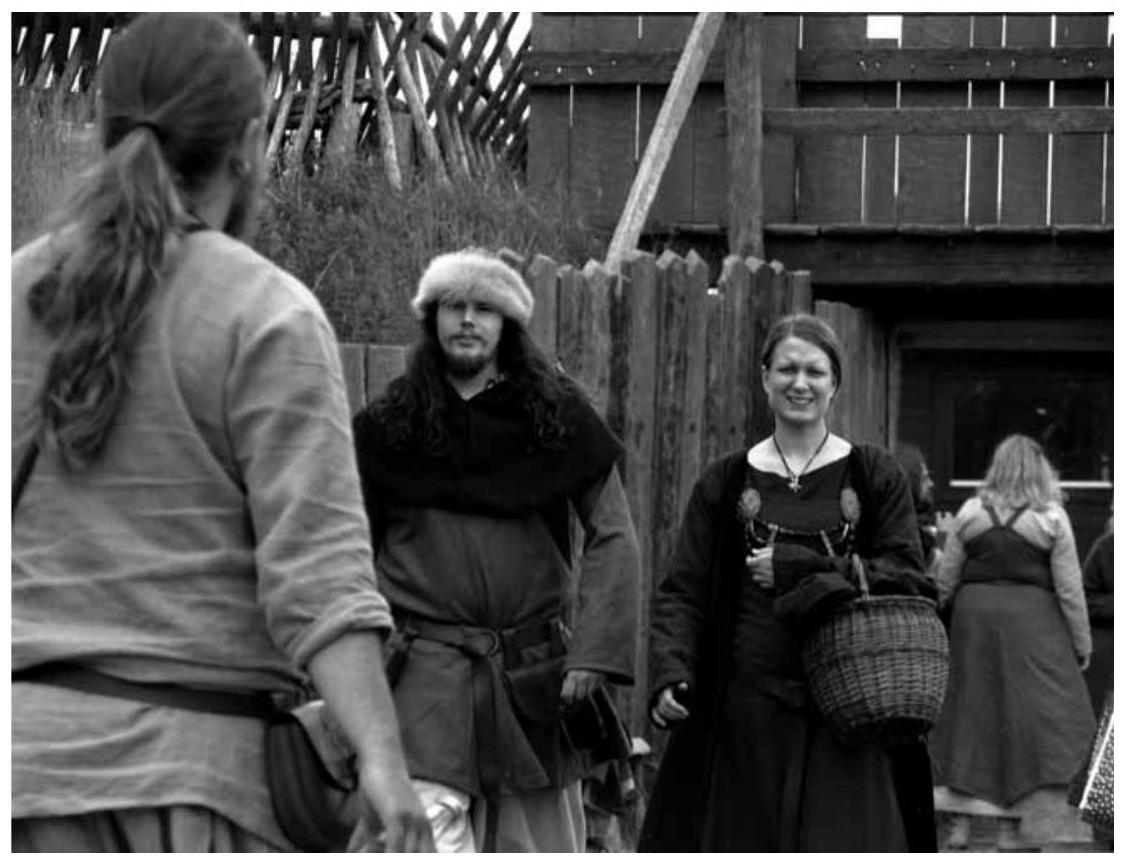

Figure 4. A Viking woman during the Viking Market. Photo: Dawid Kobiałka.

Figure 5. Material culture produced by a Swedish historical re-enactor. Photo: Dawid Kobiałka. 


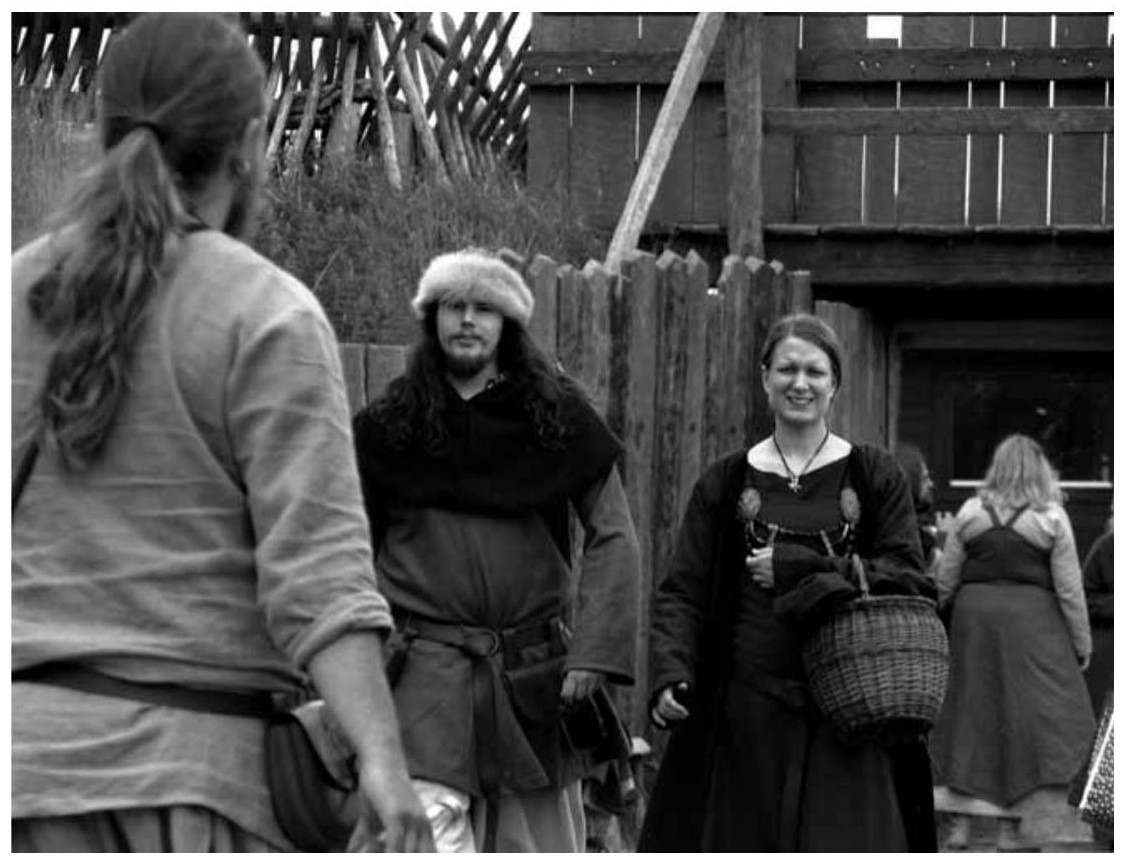

Figure 4. A Viking woman during the Viking Market. Photo: Dawid Kobiałka.

Figure 5. Material culture produced by a Swedish historical re-enactor. Photo: Dawid Kobiałka. 


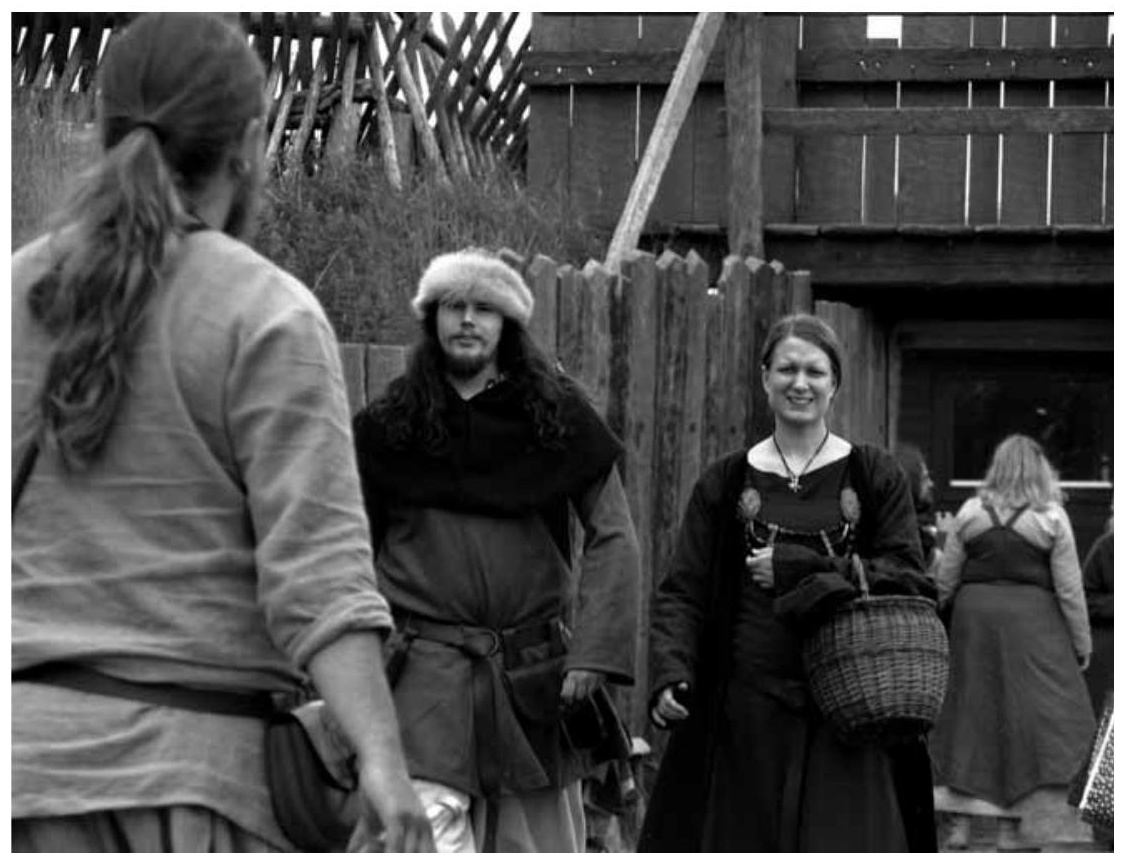

Figure 4. A Viking woman during the Viking Market. Photo: Dawid Kobiałka.

Figure 5. Material culture produced by a Swedish historical re-enactor. Photo: Dawid Kobiałka. 


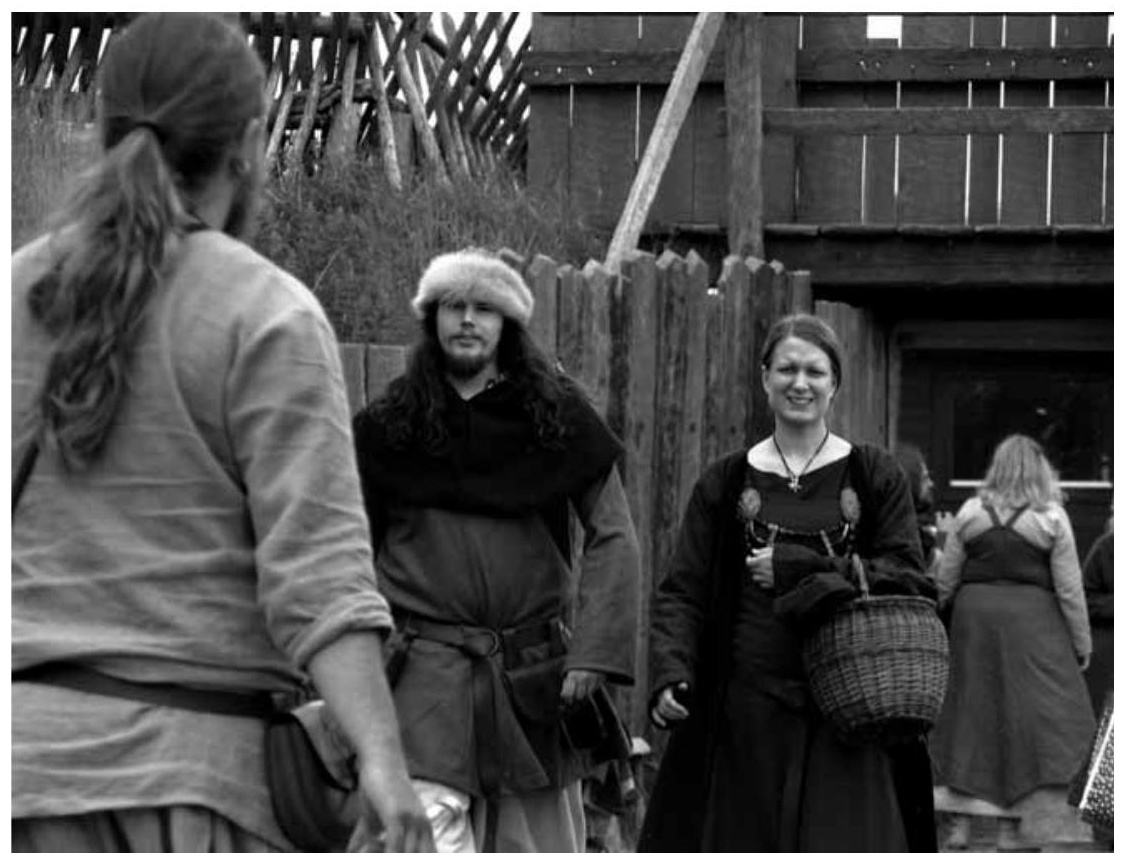

Figure 4. A Viking woman during the Viking Market. Photo: Dawid Kobiałka.

Figure 5. Material culture produced by a Swedish historical re-enactor. Photo: Dawid Kobiałka. 


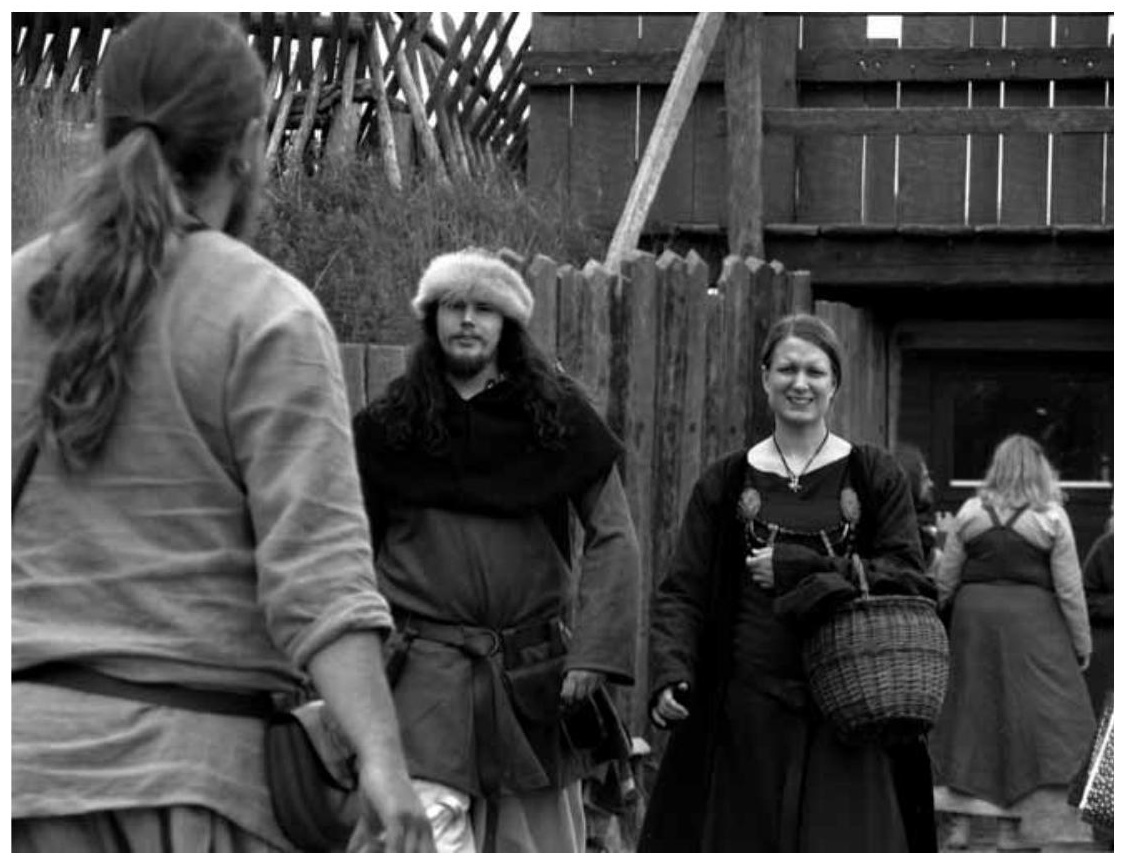

Figure 4. A Viking woman during the Viking Market. Photo: Dawid Kobiałka.

Figure 5. Material culture produced by a Swedish historical re-enactor. Photo: Dawid Kobiałka. 


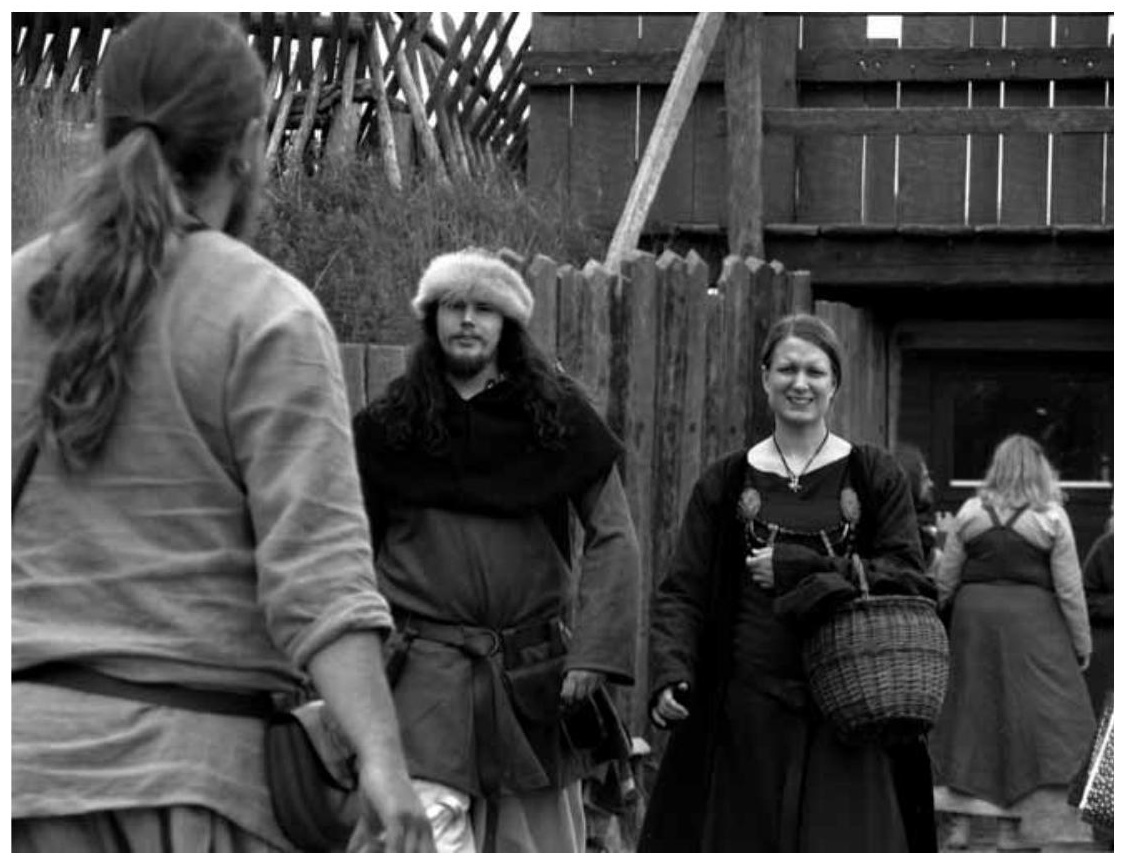

Figure 4. A Viking woman during the Viking Market. Photo: Dawid Kobiałka.

Figure 5. Material culture produced by a Swedish historical re-enactor. Photo: Dawid Kobiałka. 